\title{
PERAN ORANG TUA MENINGKATKAN MOTIVASI BELAJAR MATEMATIKA SISWA SELAMA PANDEMI COVID-19 DI LINGKUNGAN III KECAMATAN SOSORGADONG
}

\author{
Oleh: \\ Maswaras Hari Hutagalung1, Zulfadli², Eva Yanti Siregar ${ }^{3}$ \\ Fakultas MIPA, Institut Pendidikan Tapanuli Selatan (IPTS) Padangsidimpuan
}

\begin{abstract}
The background of this research is Covid- 19 pandemic that caused feeling boring of students in learning. This case requires the parents to help the students in learning at home and giving motivation so the students to get maximum achievement. The aim of this study is know the role of the parent to improve students' mathematics motivation in Covid-19 pandemic period in Lingkungan III, Sosorgadong sub-distirct. The approach of the research used qualitative descriptive and subject is all students (SMP) in Lingkungan III, Sosorgadong sub-distirct. Questionnaire and interview were used in collecting the data. the result of the research shows the role of the parents to improve students' mathematics motivation in Covid-19 pandemic period includes accompanying, controlling, supervising the students in teaching learning, and completing facilities the students.
\end{abstract}

Keywords: the role of the parents, mathematic learning motivation, Covid-19 pandemic

\section{Abstrak}

Latar belakang penelitian ini adalah pandemi Covid-19 yang menyebabkan siswa merasa bosan dalam belajar. Hal ini menuntut orang tua membantu siswa dalam belajar di rumah dan memberikan motivasi agar siswa dapat berprestasi secara maksimal. Penelitian ini bertujuan untuk mengetahui peran orang tua dalam meningkatkan motivasi belajar matematika siswa pada periode pandemi Covid-19 di Lingkungan III Kecamatan Sosorgadong. Pendekatan penelitian yang digunakan adalah deskriptif kualitatif dan subjeknya adalah seluruh siswa (SMP) di Lingkungan III Kecamatan Sosorgadong. Angket dan wawancara digunakan untuk mengumpulkan data. Hasil penelitian menunjukkan peran orang tua dalam meningkatkan motivasi belajar matematika siswa pada periode pandemi Covid-19 meliputi mendampingi, mengontrol, mengawasi siswa dalam proses belajar mengajar, dan melengkapi fasilitas siswa.

Kata kunci: peran orang tua, motivasi belajar matematika, pandemi Covid-19

\section{PENDAHULUAN}

Pada awal bulan maret 2020 indonesia terserang wabah covid-19 yang pada akhirnya berubah menjadi pandemi, yang berdampak dalam kehidupan sehari-hari terutama dalam bidang pendidikan. Masa pandemi covid-19 ini tentu memunculkan rasa bosan pada peserta didik. Dalam hal ini peran orang tua sangat penting, selain membantu proses pembelajaran dirumah, orang tua juga harus memberikan motivasi terhadap peserta didik, supaya peserta didik tidak merasa bosan dalam mengerjakan tugas yang diberikan oleh guru dan mendapatkan hasil yang maksimal.

Motivasi merupakan sebuah dorongan yang timbul pada diri seseorang secara sadar atau tidak sadar untuk melakukan suatu tindakan sesuai dengan tujuan tertentu. Motivasi belajar merupakan keseluruhan daya penggerak di dalam diri siswa (anak) yang sanggup menimbulkan kegiatan belajar, yang menjamin kelangsungan dari kegiatan belajar dan yang memberikan arah pada kegiatan belajar, sehingga tujuan yang dikehendaki oleh subjek belajar (anak didik/siswa) dapat tercapai.

Peran orang tua yang seharusnya adalah sebagai orang pertama dalam meletakkan dasardasar pendidikan terhadap anak-anaknya. Dengan hal tersebut, kehidupan keluarga terutama peran 
orang tua merupakan lingkungan pendidikan pertama yang mempunyai peranan penting dalam menentukan dan membina proses perkembangan anak. Tidak menutup kemungkinan bahwa masalah yang dialami siswa di sekolah seperti rendahnya prestasi belajar siswa dan berhasil tidaknya proses belajar siswa merupakan akibat atau lanjutan dari situasi lingkungan keluarga yang tidak harmonis dan peran orang tua yang tidak dijalankan dengan baik.

Motivasi belajar siswa juga terkait dengan peran orang tua, dimana peran orang tua tersebut memberikan pengaruh yang besar. Namun pada kasus yang terjadi banyak orang tua yang masih belum memahami dan menyadari perannya dalam pendidikan anak termasuk dengan motivasi belajar siswa. Orang tua yang tidak tahu peran mereka dalam membantu siswa atau anaknya dalam pendidikan, sehingga terkadang orang tua hanya mengetahui dan bertanggungjawab sekedar menyekolahkan anaknya tetapi mengabaikan pendidikan dari orang tua itu sendiri, termasuk dorongan dan motivasi belajar bagi anak tersebut. Padahal seperti yang diketahui bahwa pendidikan yang pertama kali dikenal oleh anak adalah dari keluarga dimana orang tua sangat berperan penting di dalamnya. Peran motivasi orang tua dalam belajar matematika pada masa pandemi covid-19 sangat penting. Dengan adanya pemahaman dan kesadaran orang tua akan peran motivasi belajar matematika pada masa pandemi covid-19 dapat membantu menyelesaikan masalah belajar dirumah. Oleh karena itu peneliti tertarik mengangkat judul peran orang tua meningkatkan motivasi belajar matematika siswa di Lingkungan III Kecamatan Sosorgadong

\section{Peran Orang Tua (Ayah dan Ibu)}

Kata "peran" diambil dari istilah teater dan merupakan bagian yang tak terpisahkan dari kelompok-kelompok masyarakat. Arti peran adalah bagian yang kita mainkan pada setiap keadaan dan cara bertingkah laku untuk menyelaraskan diri kita dengan keadaan. Peranan (role) merupakan aspek yang dinamis dari kedudukan (status). Apabila seseorang melaksanakan hak-hak dan kewajiban- kewajibannya sesuai dengan kedudukannya. Menurut kamus besar bahasa Indonesia (KBBI) "Peran adalah tingkah seseorang yang diharapkan dimiliki oleh orang yang berkedudukan dimasyarakat. Menurut Rumbewas, dkk (Hamalik, 2007:33) "Peran adalah pola tingkah laku tertentu yang merupakan ciri-ciri khas semua petugas dari pekerjaan atau jabatan tertentu". Berdasarkan pendapat ahli diatas penulis menyimpulkan peran adalah seperangkat perilaku antar pribadi, sifat, kegiatan yang berhubungan dengan pribadi dalam posisi dan situasi tertentu.

Orang tua merupakan setiap orang yang bertanggung jawab dalam suatu keluarga atau tugas rumah tangga yang dalam kehidupan sehari-hari sebagai bapak dan ibu. Menurut Oktaviani (Miami, 2010:2) "Orang tua adalah pria dan wanita yang terikat dalam perkawinan dan siap sedia untuk memikul tanggung jawab sebagai ayah dan ibu dari anak-anak yang dilahirkannya. Menurut Mardiyah (2015:109) "Orang tua merupakan orang-orang pertama yang dikenal anak. Melalui orang tualah anak mendapatkan kesan-kesan pertama tentang dunia luar. Orang tua merupakan orang pertama yang membimbing tingkah laku. Terhadap tingkah laku anak mereka bereaksi dengan menerima, menyetujui, membenarkan, menolak, atau melarang dan sebagainya". Berdasarkan pendapat ahli diatas penulis menyimpulkan Orang tua merupakan orang-orang pertama yang dikenal anak. Melalui orang tualah anak mendapatkan kesan-kesan pertama tentang dunia luar. Orang tua merupakan orang pertama yang membimbing tingkah laku. Terhadap tingkah laku anak mereka bereaksi dengan menerima, menyetujui, membenarkan, menolak, atau melarang dan sebagainya.

Peran orang tua adalah perilaku yang berkenaan dengan orang tua dalam memegang posisi tertentu di keluarga sebagai pengasuh, pembimbing dan pendidik bagi anak. Menurut Haerudin, dkk (Abu Ahmadi, 2004:43) menyatakan "Peran orang tua adalah suatu hal kompleks pengharapan manusia terhadap caranya individu harus bersikap yang mempunyai tanggung jawab dalam keluarga". Menurut Rumbewas, dkk (Lestari, 2012) menyatakan bahwa "Peran orang tua adalah cara-cara yang digunakan oleh orang tua mengenai tugas-tugas yang mesti dijalankan dalam mengasuh anak". Berdasarkan pendapat ahli diatas penulis menyimpulkan Peran orang tua yaitu sebagai fasilitator, motivator dan pembimbing. Orangtua memiliki tanggung jawab untuk mendidik, mengasuh dan membimbing anak-anaknya untuk mencapai tahapan tertentu yang menghantarkan anak untuk siap dalam kehidupan bermasyarakat, sedangkan pengertian orangtua di atas, tidak terlepas dari pengertian keluarga, karena orangtua merupakan bagian keluarga besar yang sebagian besar telah tergantikan oleh keluarga inti yang terdir dari ayah, ibu dan anak-anak. 
Bentuk peran orangtua sebenarnya sama dengan bentuk peran yang diberikan guru di sekolah. Bentuk-bentuk peran peran orangtua tersebut antara lain:

a. Orangtua sebagai motivator

Orangtua mempunyai tugas untuk memotivasi dalam mempelajari segala hal. Motivasi yang diberikan bisa dalam bentuk memfasilitasi kebutuhan- kebutuhan disekolah, pemberian spirit dalam bentuk pujian atau hadiah attas prestasi yan diraih. Sekecil apapun hadiah itu sangat berharga uat mereka karena dapat membuat mereka lebih bersemangat dan senang dalam belajar, atau bisa juga menjadi pendamping mereka dalam belajar.

b. Orangtua sebagai Guru

Orangtua sebagai guru memiliki tugas mendidik dan mengajar anak- anaknya. Oleh karena itu orangtua dituntut untuk bersikap lebih sabar dalam membimbing dan mengarahkan mereka sebagaimana tugas guru di sekolah sehingga saling melengkapi dan sangat membantu memecahkan masalah-masalah atau kesulitan-kesulitan yang dihadapi anak-anak baik di sekolah maupun di rumah.

c. Orangtua sebagai penegak disiplin

Orangtua bertugas menanamkan dan menegakkan kedisiplinan. Pendisiplinan terhadap anak sangat penting, namun bukan berarti pendisiplinan yang kaku. Anak perlu dibiasakan dalam hidup keteraturan. Hubungannya dengan usaha meningkatan prestasi, orangtua dapat membuatkan jadwal pembagian tugas dirumah dan jadwal belajar mereka. Penerapan pendisiplinan secara teratur lama kelamaan akan dirasakan anak, sehingga ia tidak merasa terikat oleh peraturan, namun akan menjalaninya dengan rutin atas dasar kesadaran.

d. Orangtua sebagai pengontrol

Orangtua hendaknya selalu mengikuti perkembangan prestasi anak serta mengontrol perilakunya yang baik di rumah maupun di sekolah dengan melakukan pendekatn informasi dan kelompok informasi dan kelompok musyawaroh antara guru dan orangtua. Dengan demikian orangtua dapat mengetahui sebab-sebab dari maju mundurnya prestasi anak serta dapat menyikapi problem yang dihadapi anak secara bijak.

\section{Motivasi belajar}

Motivasi adalah dorongan, keinginan untuk melakukan suatu kegiatan atau pekerjaan dengan memberikan yang terbaik pada dirinya demi tercapainya tujuan yang di inginkan. Yamin (Mc. Donald, 2011:158) “ Motivasi adalah perubahan energi dalam diri (pribadi) seseorang yang ditandai dengan timbulnya perasaan dan reaksi untuk mencapai tujuan. Menurut Kusuma dan Subkhan (2015:166) "Motivasi adalah semacam dorongan terhadap seseorang atau kelompok yang muncul dari dalam diri seseorang atau kelompok atau juga bisa ditimbulkan oleh faktor luar diri individu atau kelompok. Berdasarkan pendapat beberapa ahli diatas penulis menyimpulkan Motivasi adalah semacam dorongan terhadap seseorang atau kelompok yang muncul dari dalam diri seseorang atau kelompok atau juga bisa ditimbulkan oleh faktor luar diri individu atau kelompok.

Belajar adalah sebuah proses perubahan di dalam kepribadian manusia dan perubahan tersebut ditampakkan dalam bentuk peningkatan kualitas dan kuantitas tingkah laku seperti peningkatan kecakapan, pengetahuan, sikap, kebiasaan, pemahaman, keterampilan, daya pikir dan kemampuan-kemampuan yang lain. Menurut Slameto (2015:2) "Belajar adalah suatu proses usaha yang dilakukan seseorang untuk memperoleh suatu perubahan tingkah laku yang baru secara keseluruhan, sebagai hasil pengalamannya sendiri dalam interaksi dengan lingkungannya". Menurut Dimyati dan Mudjiono (Skinner, 2010:9) "Belajar adalah suatu perilaku. Pada saat orang belajar, maka responsnya menjadi lebih baik. Sebaliknya, bila ia tidak belajar maka responsnya menurun". Berdasarkan pendapat beberapa ahli diatas penulis menyimpulkan Belajar adalah suatu proses usaha yang dilakukan seseorang untuk memperoleh suatu perubahan tingkah laku yang baru secara keseluruhan, sebagai hasil pengalamannya sendiri dalam interaksi dengan lingkungannya.

Motivasi belajar merupakan keseluruhan daya penggerak baik dari dalam diri maupun dari luar siswa yang menjamin kelangsungan dan memberikan arah pada kegiatan belajar sehingga tujuan yang dikehendaki oleh siswa dapat tercapai. Menurut Arief, dkk (De Decce \& Grawford, 2016:142) menyatakan bahwa "Motivasi belajar siswa harus senantiasa ditumbuhkan dan dipelihara pada diri siswa sebagaimana fungsi dari motivasi belajar yaitu guru harus dapat membangkitkan semangat siswa dalam belajar, memberikan harapan yang nyata, memberi insentif dan mengarahkan siswa pada perilaku yang sesuai dengan tujuan yang telah ditetapkan”. Menurut 
Hamdu (Clayton Alderfer, 2004:42) "Motivasi belajar adalah kecenderungan siswa dalam melakukan kegiatan belajar yang didorong oleh hasrat untuk mencapai prestasi atau hasil belajar sebaik mungkin”. Berdasarkan beberapa pendapat para ahli diatas penulis menyimpulkan bahwa Motivasi belajar adalah dorongan mental yang menggerakkan dan mengarahkan perilaku manusia ke dalam bentuk aktivitas nyata untuk memperoleh suatu perubahan tingkah laku sebagai hasil dari pengalaman individu dalam interaksi dengan lingkungannya yang menyangkut kognitif, afektif, dan psikomotorik.

\section{Pembelajaran Matematis}

Pembelajaran merupakan aspek penting dalam implentasi kurikulum baik pada satuan pendidikan maupun perguruan tinggi. Menurut Ratumanan dan Tetelepta (2019:24) "Istilah pembelajaran lebih menggambarkan bahwa siswa lebih banyak berperan dalam mengkonstruksikan pengetahuan bagi dirinya, dan bahwa pengetahuan itu bukan hasil proses transformasi dari guru. Menurut Sanjaya (2009:215) “ Pembelajaran merupakan istilah lain dari mengajar. Dalam kegiatan pembelajaran siswa harus dijadikan sebagai pusat dari kegiatan. Hal ini dimaksudkan untuk membentuk watak, peradaban, dan meningkatkan mutu kehidupan peserta didik. Berdasarkan beberapa pendapat ahli diatas peneliti menyimpulkan bahwa pembelajaran adalah suatu kegiatan yang dilakukan untuk membentuk watak, sikap, peradaban, dan untuk meningkatkan mutu kehidupan peserta didik. Proses pembelajaran akan menentukan pencapaian yang telah ditetapkan.

Matematika berasal dari bahasa yunani "Mathein" yang berarti mempelajari. Kata tersebut mempunyai hubungan yang erat dengan bahasa sanskerta yang berasal dari kata "Medha" atau "Widya" yang mempunyai arti kepandaian, ketahuan. Lebih tepatnya matematika disebut ilmu pasti, karena dengan menguasai matematika orang akan belajar mengatur jalan pikirannya dan belajar menambah kepandaiannya. Menurut Suherman (2003) "Matematika adalah disiplin ilmu tentang tata cara berpikir dan mengolah logika, baik secara kuantitatif maupun kualitatif". Menurut Suhendri (Ningsih dan Nurrahma, 2016:75) "Matematika adalah ilmu tentang bilangan, bangun, hubungan-hubungan konsep, dan logika dengan menggunakan bahasa lambang atau simbol dalam menyelesaikan masalah-masalah dalam kehidupan sehari-hari. Berdasarkan beberapa pendapat ahli diatas peneliti menyimpulkan bahwa matematika adalah Matematika adalah disiplin ilmu tentang tata cara berpikir dan mengolah logika, baik secara kuantitatif maupun kualitatif.

Ruseffendi (2006:156) “ Pembelajaran matematika dibuat untuk meningkatkan pengajaran matematika yang lebih mengutamakan kepada pengertian, sehingga matematika itu lebih mudah dipelajari dan lebih menarik. Dari uraian diatas peneliti menyimpulkan bahwa pembelajaran matematika adalah usaha sadar yang bertujuan untuk menciptakan suasana lingkungan yang memungkinkan siswa dalam belajar matematika agar tercipta komunikasi matematika yang baik sehingga matematika itu lebih mudah dipelajari dan lebih menarik.

\section{Peran Orang Tua Meningkatkan Motivasi Belajar Matematika Siswa}

Keberhasilan siswa dalam proses belajarnya tidak dapat terlepas dari adanya motivasi yang menjadi penggerak dan pendorong siswa agar dapat menjalankan kegiatan dan proses belajarnya. Motivasi tersebut dapat berasal dari dalam diri siswa (intrinsik) dan motivasi dari luar (ekstrinsik). Dari kedua motivasi tersebut memiliki pengaruh yang besar terhadap keberhasilan siswa, meskipun yang lebih utamanya adalah motivasi dalam diri siswa tetapi motivasi dari luar atau ekstrinsik tetap menjadi faktor yang ikut mempengaruhi kegiatan belajar siswa. Salah satu contoh motivasi yang berasal dari luar diri siswa adalah orang tua, dimana orang tua merupakan orang yang pertama kali dikenal dan dekat dengan anak, keberadaan siswa antara di sekolah dengan di rumah, maka dari itu peran orang tua sebagai orang yang dekat dengan siswa dinilai sangat penting terutama dalam memotivasi belajar siswa. Diantara peran orang tua dalam memotivasi belajar siswa adalah sebagai berikut:

a. Mengontrol waktu belajar dan cara belajar anak.

b. Memantau perkembangan kemampuan akademik anak. Orang tua diminta untuk memeriksa nilai-nilai ulangan dan tugas anak mereka.

c. Memantau perkembangan kepribadian yang mencakup sikap, moral dan tingkah laku anak-anak. Hal ini dapat dilakukan orang tua dengan berkomunikasi dengan wali kelas untuk mengetahui perkembangan anak di sekolah. 
d. Memantau efektifitas jam belajar di sekolah. Orang tua dapat menanyakan aktifitas yang dilakukan anak mereka selama berada di sekolah.

Menurut Rumbewas, dkk (2018:204-205) Terkait dengan peran orang tua dalam memotivasi belajar siswa, maka ada beberapa cara yang akan dilakukan oleh orang tua untuk meningkatkan motivasi belajar siswa, diantaranya sebagai berikut:

a. Menciptakan iklim rumah yang mendukung anak untuk belajar orang tua dapat menyediakan berbagai perlengkapan maupun permainan yang dapat mendukung anak untuk belajar, misalnya: computer, buku-buku, puzzle, dan sebagainya.

b. Menyediakan waktu yang cukup untuk terlibat dalam kegiatan belajar anak. Selain menciptakan iklim rumah yang dapat mendukung anak untuk belajar, interaksi orang tua dengan anak ternyata juga dapat meningkatkan motivasi belajar anak. Hal ini dapat dilakukan dengan menemani anak belajar, menunjukkan perhatian terhadap kegiatan belajar anak, memberikan bantuan ketika anak menghadapi kesulitan, dan sebagainya. Sebagai partner anak dalam belajar, orang tua sebaiknya menunjukkan sikap yang hangat dan positif terhadap anak, misalnya dengan tidak memarahi anak ketika tidak dapat mengerjakan tugasnya dengan baik.

c. Memberikan penghargaan atau respon positif terhadap setiap prestasi anak. Hal ini dapat dilakukan dengan berbagai cara, misalnya: dengan memberikan hadiah atau pujian. Dengan demikian, anak merasa dihargai dan lebih termotivasi untuk melakukan sesuatu.

\section{Hakikat Pandemi Covid-19}

Menurut Yuliana dalam Haerudin, dkk (2020:4) “ Coronavirus merupakan virus yang termasuk RNA strain yang tunggal positif yang menginfeksikan saluran pada pernapasan, yaitu mempunyai tanda gejala berupa demam, batuk, dan sulit dalam sistem pernapasan”. Sedangkan menurut Adityo, dkk dalam Haerudin, dkk (2020:4) menyatakan " Covid-19 merupakan penyakit yang terbaru sehingga menjadi pandemi. Penyakit ini merupakan penyakit yang menular yang relatif sangat cepat sehingga memiliki inpratalitas yang tidak bisa diabaikan, sebelum terdapat definitif'. Berdasarkan beberapa pendapat ahli diatas peneliti menyimpulkan bahwa covid-19 merupakan suatu penyakit yang disebabkan virus yang penularannya sangat cepat dan mempunyai gejala ketika sudah terkena virus corona (Covid-19) antara lain batuk, demam, dan sulit pada saluran pernapasan.

Covid-19 dapat menyebar dari orang ke orang melalui percikan-percikan dari hidung atau mulut yang keluar saat orang yang terjangkit covid-19 batuk atau mengeluarkan napas. Percikan yang keluar tersebut akan jatuh dan mengenai benda serta permukaan lain disekitarnya. Apabila benda atau permukaan tersebut disentuh atau tersentuh tangan, kemudian tangan tersebut menyentuh mata, hidung, atau mulutnya, maka orang tersebut akan terjangkit covid-19. Jika seseorang terinfeksi covid-19, maka akan mengalami gejala sebagai berikut:

a. Demam selama beberapa hari

b. Batuk

c. Nyeri tenggorokan

d. Kesulitan bernapas

e. Flu/pilek

Tindakan pencegahan covid-19 yang dapat dilakukan yaitu dengan menjaga kebersihan diri dan rumah dengan cara:

a. Mencuci tangan dengan sabun setidaknya selama 20 detik atau menggunakan handsanitize.

b. Hindari menyentuh mata, hidung, dan mulut dengan tangan yang belum dicuci.

c. Hindari interaksi fisik dengan orang yang memiliki gejala sakit.

d. Tidak berjabat tangan.

e. Menutup mulut saat batuk dan bersin dengan lengan atas bagian dalam atau dengan tisu. 
f. Segera mengganti baju/mandi setelah berpergian.

g. Menyemprotkan desinfektan secara berkala pada benda-benda terutama yang sering disentuh seperti gagang pintu, dan lainnya.

\section{METODE PENELITIAN}

Metode penelitian dalam penelitian ini menggunakan metode penelitian Deskriptif kualitatif. Penelitian Deskriptif adalah penelitian yang dilakukan untuk mengetahui nilai variabel bebas, baik satu variabel atau lebih (independen) tanpa membuat perbandingan, atau menghubungkan antara variabel yang satu dengan yang lain. Metode penelitian kualitatif adalah pengumpulan data pada suatu latar alamiah dengan menggunakan metode alamiah dan dilakukan oleh orang atau peneliti yang tertarik secara alami. Sugiyono (2018:15) "Metode penelitian kualitatif adalah metode penelitian yang berlandaskan pada filsafat postpositivisme, digunakan untuk meneliti pada kondisi obyek yang alamiah, (sebagai lawannya adalah eksperimen) dimana peneliti adalah sebagai instrumen kunci, pengambilan sampel sumber data dilakukan secara purposive dan snowball, teknik pengumpulan dengan triangulasi (gabungan), analisis data bersifat induktif/kualitatif, dan hasil penelitian kualitatif lebih menekankan makna dari pada generalisasi".

\section{a. Objek dan Informan Penelitian}

Objek dalam penelitian ini yaitu peran orang tua meningkatkan motivasi belajar matematika siswa selama pandemi COVID-19. Informan dalam penelitian ini adalah guru dan siswa SMP berjumlah 10 siswa yang bertempat tinggal di Lingkungan III Kecamatan Sosorgadong.

\section{b. Data dan Sumber Data}

Data yang diperoleh nantinya diolah sehingga menjadi informasi yang lebih baru. sumber data dalam penelitian ini menggunakan sumber data primer dan sumber data sekunder. sumber data primer dalam penelitian ini adalah siswa itu sendiri, Sedangkan, sumber data primer yang diperoleh baik dari jurnal pendidikan dan buku pendidikan.

\section{c. Teknik Pengumpulan Data}

1. Wawancara

Wawancara adalah proses memperoleh keterangan/data untuk tujuan penelitian dengan tanya jawab, sambil bertatap muka antara pewawancara dengan responden dengan menggunakan alat yang dinamakan panduan wawancara. Menurut Sugiyono (Esterberg, 2018:317) "Wawancara adalah pertemuan dua orang untuk bertukar informasi dan ide melalui tanya jawab, sehingga dapat dikonstruksikan makna dalam suatu topik tertentu".

\section{Angket}

Kuesioner (Angket) adalah suatu teknik pengumpulan data yang digunakan peneliti untuk mengumpulkan data dengan cara menyebarkan sejumlah lembar kertas yang berisis pertanyaanpertanyaan yang harus dijawab responden. Menurut Silalahi (2012:296) "Kuesioner atau angket merupakan satu mekanisme pengumpulan data yang efisien bila peneliti mengetahui secara jelas apa yang disyaratkan dan bagaimana mengukur variabel yang diminati.

\section{d. Teknik Keabsahan Data}

Keabsahan data merupakan bentuk batasan yang berkaitan dengan suatu kepastian. Untuk mengetahui keabsahan data dilakukan dengan menggunakan triangulasi sumber dan triangulasi.

\section{e. Teknik Analisis Data}

1. Reduksi Data

Reduksi data merupakan proses berpikir sensitif yang memerlukan kecerdasan dan keluasan dan kedalaman wawasan yang tinggi. Menurut Sugiyono (2018:338) mengatakan "Mereduksi data berarti merangkum, memilih hal-hal yang pokok, memfokuskan pada ha-hal yang penting, dicari tema dan polanya dan membuang yang tidak perlu". Dengan demikian data yang telah direduksi akan memberikan gambaran yang lebih jelas, dan mempermudah peneliti untuk melakukan pengumpulan data selanjutnya, dan mencarinya bila diperlukan. Menurut Rangkuti (2014:156) "Mereduksi data berarti merangkum, memilih hal-hal yang pokok, memfokuskan pada hal-hal yang penting, dicari tema dan polanya dan membuang yang tidak perlu". Berdasarkan beberapa pendapat ahli diatas peneliti menyimpulkan reduksi data adalah proses merangkum dan memilih 
data mana yang dicari dan membuang yang tidak perlu. Dengan demikian data yang telah direduksi akan memberikan gambaran yang lebih jelas, dan mempermudah peneliti untuk melakukan pengumpulan data selanjutnya, dan mencarinya bila diperlukan.

2. Penyajian Data

Rangkuti (2014:157) "Data display didefinisikan juga sebagai data organized, suatu cara pengkompresan informasi yang memungkinkan suatu kesimpulan atau tindakan diambil sebagai bagian dari analisis". Miles dan Huberman (2002) dalam Ahmad Nizar Rangkuti (2014:157) "Dengan mendisplaykan data, maka akan memudahkan untuk memahami apa yang terjadi, merencanakan kerja selanjutnya berdasarkan apa yang telah dipahami tersebut". Menurut Silalahi (2012:340) "Penyajian data adalah sekumpulan data informasi tersusun yang memberi kemungkinan adanya penarikan kesimpulan dan pengambilan tindakan”. Berdasarkan beberapa pendapat ahli diatas peneliti menyimpulkan penyajian data adalah suatu penyajian data yang dilakukan untuk memudahkan dalam memahami apa yang terjadi, merencanakan kerja selanjutnya berdasarkan apa yang telah dipahami tersebut.

3. Kesimpulan dan Verifikasi Data

Rangkuti (2014:158) mengatakan "Kesimpulan dan verifikasi data merupakan tindakan penelitian dalam menginterpretasikan data, menggambarkan makna dari data display". Menurut Sugiyono (2018:345) mengatakan "Kesimpulan dalam penelitian kualitatif yang diharapkan adalah temuan baru yang sebelumnya belum pernah ada. Temuan dapat berupa deskripsi atau gambaran obyek yang sebelumnya masih reman-remang atau gelap sehinga setelah diteliti menjadi jelas". Berdasarkan pendapat ahli diatas peneliti menyimpulkan kesimpulan dan verifikasi data adalah langkah akhir yang dilakukan dalam suatu penelitian untuk menemukan temuan baru yang sebelumnya belum pernah ada.

\section{HASIL DAN PEMBAHASAN \\ TEMUAN UMUM}

Sosorgadong adalah sebuah kecamatan yang berada di Kabupaten Tapanuli Tengah, Provinsi Sumatera Utara, yang di pimpin oleh camat Ridwan Gorat. Sosorgadong berbatasan langsung dengan samudera Hindia di Selatan, Barus di sebelah Barat, Sorkam di sebelah Timur dan pakkat, Manduamas di sebelah Utara. Kecamatan sosorgadong terdiri dari desa Barambang, Sosorgadong, Siantar CA, Muara Bolak, Siantar Dolok, Baringin, Huta Tombak, Sibintang dan Unte Boang. Letak sosorgadong yang terdiri dari pegunungan dan daratan di tepi laut, membuat cuaca di daerah tersebut tidak terlalu panas walaupun samudera hindia tidak terlalu jauh dari pegunungan yang cuma berjarak 2 KM dari pemukiman warga. Penelitian ini dilakukan di lingkungan III Kecamatan Sosorgadong, yang di pimpin oleh lurah Risman Sitanggang, S. Pd yang memiliki masyarakat kurang lebih sekitar \pm 300 penduduk. Lingkungan III Sosorgadong adalah desa yang mata pencarian masyarakatnya bertani, buruh kasar kategori masyarakat menengah kebawah dan nelayan. Jarak/letak geografis lingkungan III dari ibu kota kecamatan sosorgadong sekitar \pm 1.500 meter. Lingkungan III Kecamatan Sosorgadong salah satu desa yang terkena dampak pandemi covid-19 sehingga siswa yang berada di lingkungan III Kecamatan Sosorgadong melaksanakan pembelajaran daring dan sesuai dengan protokol kesehatan sesuai dengan peraturan sekolah masing-masing. Mengingat pentingnya peranan orang tua dalam mendidik anak, penelitian-penelitian yang ada telah membuktikan bahwa orang tua memiliki andil yang sangat besar dalam kemampuan anak dalam lingkungan pendidikan. Peran serta orang tua siswa dalam sistem belajar di rumah ini tidak bisa dipungkiri. Jika dokter sebagai garda terdepan dalam menangani covid-19, maka orang tua baik ayah maupun ibu sebagai garda terdepan yang mengawal anak-anaknya tetap belajar di rumah masing-masing.

\section{TEMUAN KHUSUS}

Hasil angket yang dibagikan kepada siswa SMP di Lingkungan III Kecamatan Sosorgadong. Setelah peneliti membagikan angket kepada orang tua dengan 10 item pernyataan, maka peneliti mengambil 3 perwakilan dari 10 orang tua siswa untuk dijabarkan yaitu berkategori "orang tua ikut berperan dalam meningkatkan motivasi belajar matematika siswa" dan "orang tua tidak ikut berperan dalam meningkatkan motivasi belajar matematika siswa". Angket yang 
ISSN. 2621-9832

JURNAL MathEdu (Mathematic Education Journal) http://journal.ipts.ac.id/index.php/MathEdu Vol. 4. No. 3 November 2021

dibagikan kepada orang tua hanya pertanyaannya saja yang tersedia sesuai dengan keadaan yang dialami siswa tentang peran orang tua meningkatkan motivasi belajar matematika selama pandemi covid-19. Setelah pemberian angket kemudian dilakukan wawancara dengan 10 orang siswa dan 3 orang tua siswa.

\section{PEMBAHASAN}

Penyebaran angket ini dilakukan pada tanggal 18-19 Maret 2021, informan penelitian dalam penelitian ini sebanyak 10 orang tua siswa SMP. Berdasarkan dari hasil jawaban yang diperoleh dari penyebaran angket tentang peran orang tua meningkatkan motivasi belajar matematika siswa selama pandemi covid-19 diketahui 10 orang informan yang menjawab pertanyaan angket bahwa 9 dari 10 informan ikut berperan dalam meningkatkan motivasi belajar matematika siswa selama pandemi covid-19 disebabkan oleh orang tua membuat jadwal belajar di rumah selama pandemi covid-19, orang tua juga mengawasi, membantu siswa dalam belajar matematika selama pandemi covid-19. Orang tua juga mendampingi siswa belajar serta selalu memberikan motivasi belajar matematika siswa selama pandemi covid-19, orang tua juga melakukan hal-hal yang dapat menumbuhkan motivasi siswa selama covid-19 seperti mengawasi, memgontrol anak dalam belajar dan melengkapi fasilitas belajarnya. selama pandemi covid-19 orang tua juga ikut berperan dalam menyelesaikan tugas (PR ) matematika, orang tua juga mengatakan motivasi belajar matematika menurun karena mereka kurang semangat selama sekolah dialihkan kerumah, siswa lebih banyak bermain daripada belajar. Orang tua juga menuturkan dampak pandemi covid-19 terhadap motivasi belajar matematika siswa saat ini kurang semangat yang mengakibatkan siswa malas belajar, lebih banyak bermain di banding belajar, mereka menjadi belajar secara online serta dampak lain dari pandemi covid-19 tersebut siswa menjadi lebih sering di rumah, orang tua dan siswa menjadi lebih dekat. Cara dan pendapat orang tua menyikapi pandemi covid-19 supaya siswa tetap semangat dalam belajar matematika berbeda seperti orang tua memberikan semangat, memotivasi siswa dalam belajar, membantu siswa dalam menyelesaikan tugas, orang tua cenderung bersikap tegas kepada siswa agar tetap belajar serta menasehati siswa agar tetap semangat belajar walupun di tengah-tengah wabah saat ini. 1 dari 10 dari orang tua siswa tidak ikut berperan dalam meningkatkan motivasi belajar matematika siswa di lingkungan III kecamatan sosorgadong disebabkan oleh orang tua tidak selalu membantu siswa dalam belajar matematika selama pandemi covid-19 karena orang tua sibuk dengan pekerjaan mereka ayah mencari nafkah dan ibu bertani. Orang tua kadang-kadang mendampingi siswa dalam belajar dikarenakan orang tua bekerja di luar rumah, kadang-kadang orang tua ikut berperan dalam menyelesaikan tugas (PR) karena orang tua sibuk bekerja. Menurutnya motivasi belajar matematika menurun dikarenakan siswa lebih banyak bermain, dampak dari pandemi covid-19 terhadap motivasi belajar matematika siswa saat ini menurutnya kurang semangat dalam belajar dan juga malas. Cara dan pendapat orang tua menyikapi pandemi covid-19 supaya anak belajar matematika dengan memberikan semanagat agar siswa giat belajar.

\section{KESIMPULAN}

Gambaran dari hasil penelitian yang dilakukan dapat disimpulkan bahwa peran orang tua meningkatkan motivasi belajar matematika siswa selama pandemi covid-19 di lingkungan III Kecamatan Sosorgadong berdasarkan hasil angket dan wawancara dengan orang tua dapat diambil kesimpulan bahwa peran motivasi sangat penting bagi siswa terutama motivasi dari orang tua dalam belajar selama pandemic covid-19 seperti saat ini. Dapat dilihat dari orang tua mendampingi siswa belajar serta selalu memberikan motivasi belajar matematika siswa selama pandemi covid-19, orang tua juga melakukan hal-hal yang dapat menumbuhkan motivasi siswa selama covid-19 seperti mengawasi, mengontrol anak dalam belajar dan melengkapi fasilitas belajarnya selama pandemi covid-19 orang tua juga ikut berperan dalam menyelesaikan tugas (PR ) matematika, orang tua juga menyatakan motivasi belajar matematika menurun karena mereka kurang semangat selama sekolah dialihkan kerumah dan siswa lebih banyak bermain daripada belajar.

\section{IMPLIKASI}

Implikasi merupakan arah dan tindak lanjut dari makna yang terkandung dalam temuan penelitian. Dengan demikian penelitian ini memiliki implikasi terdapat peran orang tua dalam meningkat motivasi belajar matematika siswa selama pandemic covid-19 di Lingkungan III Kecamatan Sosorgadong. Oleh karena itu, diharapkan orang tua untuk lebih meningkatkan dan 
memfokuskan dalam memperhatikan siswa sehingga siswa dapat meningkatkan motivasi belajar matematika selama pandemi covid-19, sehingga siswa dapat berhasil dalam belajar dan mendapatkan prestasi yang baik.

\section{SARAN}

Berdasarkan kesimpulan dan implikasi hasil penelitian yang telah dikemukakan diatas, maka peneliti menyarankan hal-hal sebagai berikut:

1. Bagi siswa agar diharapkan untuk lebih meningkatkan minat belajarnya terhadap pelajaran matematika selama pandemi covid-19.

2. Bagi orang tua siswa diharapkan untuk selalu membantu menumbuhkan minat belajar dan selalu mengawasi siswa dalam belajar baik masa normal ataupun selama pandemi covid-19.

3. Bagi guru diharapkan memberikan bimbingan yang lebih kepada siswa sehingga dapat menumbuhkan minat belajar siswa selama pandemi covid-19.

4. Bagi peneliti lain sebagai bahan masukan dalam membuat karya ilmiah yang lebih baik lagi.

\section{DAFTAR PUSTAKA}

Arief, Habibah Sukmini, dkk. 2016. Meningkatkan Motivasi Belajar Melalui Pendekatan ProblemBased Learning (PBL). Jurnal Pena Ilmiah. Volumel II Tahun 2020.

Dimyati dan Mudjiono. 2010. Belajar dan pembelajaran. Jakarta: Rineka Cipta

Haerudin. 2020. Peran Orang Tua Dalam Membimbing Anak Selama Pembelajaran di Rumah Sebagai Upaya Memutus Covid-19.

Hamdu, Ghullam. Agustina, Lisa. 2011. Pengaruh Motivasi Belajar Siswa Terhadap Prestasi Belajar IPA di Sekolah Dasar. Jurnal Penelitian Pendidikan. Volume XII Tahun 2020.

Mardiyah. 2015. Peran orang tua dalam pendidikan agama terhadap pembentukan kepribadian anak. Jurnal kependidikan. Volume III tahun 2020.

Oktaviani, Sita. dkk. 2017. Peranan orang tua terhadap upaya perlindungan kesehatan reproduksi di desa margoyoso kecamatan sumberejo kabupaten twanggamus lampung.

Rangkuti, Ahmad Nizar. 2014. Metode Penelitian Pendidikan Pendekatan Kuantitatif, Kualitatif, PTK, dan Penelitian Pengembangan. Bandung: Citapustaka Media.

Ratumanan, Tanwey Gerson dan Tetelepta, yosep. 2019. Analisis pembelajaran matematika berdasarkan kurikulum 2013

Rumbewas, Selfia, dkk. 2018. Peran Orang Tua Dalam Meningkatkan Motivasi Belajar Peserta Didik di Sd Negeri Saribi. Jurnal EduMatSains. Volume II Tahun 2020; 201-212.

\begin{tabular}{cccc} 
Ruseffendi. 2006. & Pengertian & Pembelajaran & Matematika. \\
http://fatkhanweb.id/pengertianpembelajaranmatematika/ & Diakses & pada tanggal 10 \\
\hline Februari 2021 &
\end{tabular}

Sanjaya. 2009. Pengertian Pembelajaran Matematika. http://fatkhawanweb.id/pengertianpembelajaranmatematika/ Diakses pada tanggal 10 Februari 2021

Silalahi, Ulber. 2012. Metode Penelitian Sosial. Bandung: Refika Aditama.

Slameto. 2015. Belajar dan Faktor-Faktor yang Mempengaruhi. Jakarta: Rineka Cipta

Sugiyono. 2018. Metode Penelitian Pendidikan Pendekatan Kuantitatif, Kualitatif, dan R\&D. Bandung: Alfabeta.

Suhendri. 2018. Matematika menurut para ahli. https://mathirfanely.Wordpress.Com/matematikamenurut-para-ahli/. Diakses 11 februari 2021.

Suherman. 2018. Matematika menurut para ahli. https://mathirfanely.Wordpress.Com/matematikamenurut-para-ahli/ Diakses 11 februari 2021.

Yamin, Martinis. Kiat Membelajarkan Siswa. 2007. Jakarta: Gaung Persada Press. 